\title{
ANALISIS PENGARUH CELEBRITY ENDORSER/BRAND AMBASADOR, HARGA DAN DESAIN PRODUK YANG DIMEDIASI OLEH CITRA MEREK TERHADAP KEPUTUSAN PEMBELIAN DI ONLINE SHOP SHOPEE
}

(Studi Pada Konsumen Desstore Collection Serang Banten)

\author{
Reni Febriani ${ }^{1)}$, Mirza Abdi Khairusy ${ }^{2)}$ \\ Universitas Banten Jaya \\ Serang, Indonesia \\ renifebriani@unbaja.ac.id ${ }^{1)}$, $\underline{\text { mirza.abdi.khairusy@ gmail.com }}{ }^{2)}$
}

\begin{abstract}
This research aimed to analyze the effects of celebrity endorser/brand ambasador, price, design product on brand image to purchase decision on Shopee at online shop Desstore Collection Serang. The research object which do in this case is the Desstore Collection consumer who has made a purchase. There are 100 respondents and this research used probability sampling by using simple random sampling technic. The data analyze technic which used in this case is the structural equation model (SEM) by Partial Least Square (smart PLS 3.0). The data is primary and uses a questionnaire online with open and closed questions. The result of this research 5 hypothesis accepted and 2 hypothesis rejected. The 5 hypothesis accepted are price and brand image positively affected to purchase intention, brand ambasador, price and design product positively affected to brand image. 2 hypothesis rejected is show celebrity endorser negatively affected to purchase intention and design product not significant but positively affected to purchaseintention.
\end{abstract}

Key words: celebrity endorser/brand ambasador, price, product design, brand image, and purchase decision

\section{PENDAHULUAN}

Berkembangnya ilmu pengetahuan dan ilmu teknologi secara global dapat mempengaruhi segala aspek di dunia termasuk didalamnya ialah dunia bisnis. Seiring perkembangan dunia saat ini banyak perusahaan telah merubah sistem penjualan dan pemasaranya dari cara tradisional menjadi cara modern. Kemunculan saluran belanja baru, yaitu melalui media internet atau sosialmedia, membuat banyak perusahaan mulai mendirikan toko secara online. Peluang untuk menjalankan bisnis online semakin terbuka bagi pelaku bisnis di Indonesia. Online shopping membuat kita semakin mudah berbelanja tanpa menghabiskan waktu dan tenaga. Shopee merupakan salah satu media sosial populer, termasuk Indonesia yang memiliki berjuta anggota dari beragam tipe akun media sosial. Melihat banyaknya masyarakat yang mengunjungi situs media online untuk 
keperluan berbelanja,maka hal ini Menginspirasipengusaha-pengusaha untuk mempromosikan produk maupun jasa mereka denganbiaya promosi yang lebih hemat, melainkan dapat dijadikan media untuk memaksimalkan penjualan secara online.

Konsumen dalam memutuskan pembelian produk salah satunya dipengaruhi oleh rangsangan pemasaran, Yulihasri et.al (2001). Menurut Indraswari dan Pramudana (2014), pemasaran online merupakan salah satu bentuk komunikasi pemasaran yang menjadi fenomena sosial belakangan ini. Startegi ini digemari oleh perusahaan- perusahaan besar maupun yang tergolong usaha kecil dengan modal minim.

Belakangan ini banyak perusahaan online memilih menggunakan selebriti sebagai endorser atau brand ambassador untuk menarik hati konsumen sebagai bentuk promosi penjualan. Perusahaan harus dengan tepat dalam menentukan siapa yang akan dipilih untuk menjadi celebrity endorser atau brand ambassador dari produknya tersebut, kredibilitas seorang bintang iklan dapat dilihat dari pengetahuan khusus yag dimilikinya seperti dapat menjadi komunikator yang baik dalam menyampaikan pesan, objectivitas, dan kejujuran endorser yang dapat diterima oleh masyarakat serta daya tarik endroser itu sendiri Salestio, et. al (2016).

Faktor yang juga mempengaruhi keputusan pembelian adalah harga, harga merupakan faktor yang sensitif bagi konsumen karena konsumen selalu melakukan berbagai pertimbangan ketika melakukan keputusan pembelian. Harga merupakan salah satu penentu keberhasilan suatu perusahaan karena harga menentukan seberapa besar keuntungan yang akan diperoleh perusahaan dari penjualan produknya baik barang maupun jasa.

Salah satu faktor yang mempengaruhi keputusan pembelian adalah citra merek dari produk tersebut. Citra merek yang baik yang dimiliki sebuah produk akan mampu meningkatkan minat pembelian konsumen atas produk tersebut. Produk dengan merek yang terkenal bagus akan lebih mudah mendapat perhatian konsumen saat konsumen mempertimbangkan untuk membeli suatu produk. Citra merek dapat dipengaruhi berbagai macam hal seperti desain produk. Desain produk dianggap sebagai penampilan sebuah produk yang mampu menarik perhatian konsumen. Produk dengan desain yang menarik akan menciptakan citra merek produk tersebut.

$$
\text { Saat ini tidak sedikit }
$$
entrepreneur(pengusaha) menjadikan 
Shopee sebagai media promosi penjualan.

Salah satu entrepreneur yang bergerak pada penjualan baju muslim dan fashion lain yang juga menggunakan shopee sebagai media promosi penjualanya yaitu Desstore Collection dengan akun Shopee yang digunakan dengan nama Desstore Collection.

Desstore Collection adalah usaha kecil menengah (UMKM) yang berada di wilayah Serang Provinsi Banten tepatnya di Belakang BPUD Pendidikan Serang, Jl.

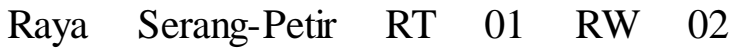
KampungCipecung Kelurahan Curug Kecamatan Kota Serang Banten 42117. Desstore Collection menawarkan berbagai model fashion busana muslim yang memproduksi gamis syari, atasan tunik dan jilbab. Desstore Collection sebelumnya berjualan melalui media sosial berupa Shopee dan WA (WhatsApp Group) sejak berdiri pada 02 Desember 2017.

\section{Berdasarkan fenomena diatas, dapat disimpulkan bahwa semakin meningkatnya persaingan penjualan online di Shopee menuntut Desstore Collection harus bersaing dengan kompetitor lama yang semakin berkembang dan kompetitor baru yang berpotensi merebut pangsa pasar dengan menawarkan produk-produk busana fashion dengan design terbaru kepada konsumen online. Untuk bisa}

merebut pasar online baju busana fashion di ShopeeDesstore Collection harus merumuskan strategi pemasaran yang jitu sehingga dapat mengungguli para pesaingnya dan tetap bertahan dalam persaingan. Faktor celebrity endorser atau brand ambasador, harga, desain produk dan citra merek merupakan faktor yang akan dipertimbangkan dalam memilih dan memutuskan membeli produk busana yang akan dibeli di Shopee.

\section{MODEL TEORITIK/ EKSPERIMEN}

Gambar 1. Model Penelitian

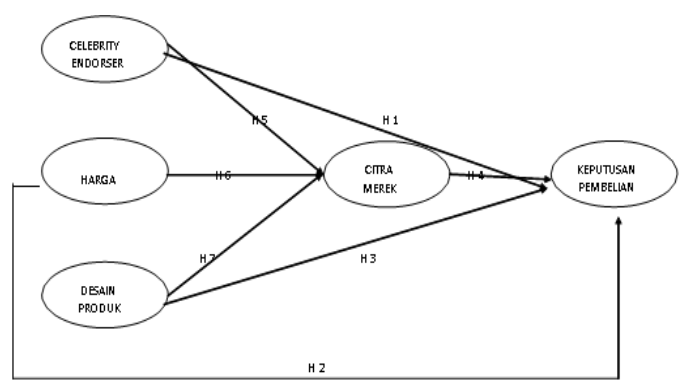

Pengaruh Celebrity Endorser Terhadap Keputusan Pembelian. Menurut Kertamukti (2015) Celebrity endorser adalah individu yang terkenal oleh publik atas prestasinya sclain daripada produk yang didukungnya, Menurut Rossiter dalam Kertamukti (2015), celebrity endorser harus memiliki 4 karakteristik yang dikenal dengan nama VisCAP (visibility-kepopuleran, credibility- 
PROGRESS

Jurnal Pendidikan, Akuntansi dan Keuangan

Universitas Banten Jaya
Vol 3 No. 1, Februari 2020

E-ISSN 2622-7037 |P-ISSN 2623-0763 kredibilitas, attractiveness-daya tarik, power)

Kepopuleran celebrity endorser sangat penting dalam pembentukan kesadaran bagi konsumen karena kesadaran masyarakat tentang bintang iklan akan meningkatkan kesadaran tentang produk. Selebriti yang dikenal olch masyarakat luas dapat menarik perhatian khalayak dan mendorong untuk melakukan pembelian produk, Kertamukti (2015). Penelitian yang dilakukan oleh Lombo dan Maria (2014) yang menyatakan bahwa celebrity endroser memberikan pengaruh yang signifikan terhadap keputusan pembelian.

Hal ini juga sejalan dengan penelitian yang dilakukan oleh Wijanarko, et.al (2016) yang menyatakan bahwa celebriry endroser dapat menarik minat konsumen untuk melakukan keputusan pembelian produk, kredibilitas selebriti adalah salah satu faktor yang mempengaruhi proses keputusan pembelian produk TOP Coffee.

Mengacu pada uraian diatas maka hipotesis yang dikembangkan adalah:

H1: Celebrity endorser berpengaruh positif dan signifikan terhadap keputusan pembelian

\section{Pengaruh Harga Terhadap Keputusan} Pembelian
Harga tidak terlepas dari produk yaitu berupa barang dan jasa. Harga adalah salah satu faktor yang terpenting dalam pemasaran karena dengan harga yang dianggap mahal, tidak semua konsumen dapat membeli barang tersebut. Harga yang kompetitif dengan

kompetitor perusahaan maka akan memberi kesempatan pada konsumen untuk memilih dan membeli.

Dalam membeli suatu produk, konsumen tidak hanya mempertimbangkan kualitas produk tetapi juga mempertimbangkan harga. Dengan penerapan harga ysng kompetitif, dipandang layak, terjangkau dan dapat bersaing diharapkan dapat menguatkan keputusan pembelian konsumen produk tersebut. Penelitian yang dilakukan oleh Evelina, DW dan Listyorini (2012), menunjukkan hahwa harga mempunyai pengaruh positif terhadap keputusan pembelian.

Mengacu pada uraian diatas maka hipotesis yang dikembangkan adalah:

$\mathrm{H} 2$ : Harga berpengaruh positif dan signifikan terhadap keputusan pembelian

\section{Pengaruh Desain Produk Terhadap}

\section{Keputusan Pembelian}

Desain merupakan perencanaan dalam pembuatan sebuah objek, sistem, komponen atau struktur. Kemudian, kata 
desain dapat digunakan sebagai kata benda maupun kata kerja. Dalam artian yang lebih luas, desain merupakan seni terapan dan rekayasa yang berintegrasi dengan teknologi. Desain dikenakan pada bentuk sebuah rencana, dalam hal ini dapat berupa proposal, gambar, model, maupun deskripsi.

Jadi dapat dikatakan, desain merupakan sebuah konsep tentang sesuatu. Desain lahir dari penerjemahan kepentingan, keperluan, data maupun jawaban atas sebuah masalah dengan metode-metode yang diangap komprehensif, baik itu riset, brainstorming, pemikiran maupun

\section{Pengaruh Citra Merek Terhadap}

\section{Keputusan Pembelian}

Konsumen dengan persepsi citra merek yang positif terhadap produk lebih memungkinkan untuk melalukan pembelian karena citra merek yang positif menjadi referensi utama bagi konsumen dalam keputusanya membeli produk. Penelitian sebelumnya yang dilakukan oleh Wu et.al (2010) membuktikan pengaruh yang positif dan signifikan citra merek terhadap keputusan pembelian, yaitu konsumen akan memastikan pembelian produk apabila citra merek produk tersebut baik dan membedakanya dari merek lain.Temuan lainya mengenai memodifikasi desain menjadi lebih inovasi yang sudah ada sebelummya.

Penelitian yang dilakukan oleh Rahman dan Santoso (2015) bahwa desain produk berpengaruh positif terhadap keputusan pembelian. Sedangkan pada penelitian yang dilakukan oleh Khadijah dan Khuzaimah (2017) pada desain produk dan keputusan pembelian mununjukan bahwa desain produk tidak berpengaruh terhadap keputusan pembelian.

Mengacu pada uraian diatas maka hipotesis yang dikembangkan adalah:

H3: Desain produk berpengaruh positif dan signifikan terhadap keputusan pembelian

hubungan citra merek dengan keputusan pembeliandikemukakan juga oleh Aghekyan-Simonian et.al (2012), bahwa citra merekmempengaruhi keputusan membeli konsumen dengan mengurangi berbagai persepsi resiko karena kepercayaan konsumen terhadap merek dan pengalaman konsumen terhadap merek tersebut. Lee et.al (2011) juga menegaskan bahwa dengan menciptakan citra merek yang baik, maka akan mendorong konsumen untuk terus membeli produk tensebut.

Mengacu pada uraian diatas maka hipotesis yang dikembangkan adalah:

H4: Citra merek berpengaruh positif dan signifikan terhadap keputusan pembelian 
Mengacu pada uraian diatas maka

\section{Pengaruh Celebrity Endorser Terhadap}

\section{Citra Merek}

McCracken (dalam Chan et al, 2013) mengatakan terdapat tiga tahap bagaimana celebrity endorser dapat mentransfer imagenya ke suatu merek yang dikenal dengan Meaning Transfer Model. Meaning Transfer Model menegaskan bahwa celebrity endorser mampu mempengaruhi citra merek. Penelitian yang dilakukan Chan et al (2013) bahwa dengan menggunakan celebrity endorser dapat meningkatkan brand awareness, encourage trial, dan tentunya meningkatkan brand image atau citra merek. Hal ini juga untuk menimbulkan perasaan yang positif pada produk tersebut.

Halonen-Knight dan Hurmerinta (2010) menyatakan bahwa pemilihan celebrity endorser bagi perusahaan, dan memilih produk yang akan dipromosikan merupakan hal yang penting bagi masingmasing pihak. Hal ini dikarenakan selebriti dan citra merek dari suatu produk saling berpengaruh, sehingga selebirti perlu menjaga integritas dan kredibilitasnya agar produk yang dipromosikannya memiliki persepsi yang positif dimata konsumen. Penelitian lain oleh Sabunwala (2013) menunjukkan bahwa citra merek terbukti dipengaruhi oleh celebrity endorser. hipotesis yang dikembangkan adalah:

H5: Celebrity endorser berpengaruh positif dan signifikan terhadap citra merek

\section{Pengaruh Harga Terhadap Citra Merek \\ Dalam memasarkan suatu produk,} harga adalah salah satu faktor utama untuk memasarkan suatu produk dalam bentuk barang jasa ataupun barang, karena harga adalah sejumlah uang yang harus dikeluarkan oleh konsumen untuk mendapatkan produk atau jasa yang dibelinya guna memenuhi kebutuhan dan keinginannya. Dengan berbagai harga yang ditawarkan maka konsumen akan mempunyai banyak pilihan produk dan konsumen menilai harga sebagai tolak ukur dalam pembelian sebuah produk. Dengan harga yang ditetapkan oleh perusahaan secara langsung maka akan berpengaruh terhadap citra merek. Sebagai contoh ketika perusahaan memasarkan produknya dengan harga yang mahalpremium maka secara langsung akan menimbulkan citra merek terhadap merek tersebut. Penelitian yang dilakukan oleh Noerhodiah (2013) menunjukkan bahwa harga berpegaruh positif terhadap citra merek.

Mengacu pada uraian diatas maka hipotesis yang dikembangkan adalah:

H6: Harga berpengaruh positif dan 
signifikan terhadap citra merek

\section{Pengaruh Desain Produk Terhadap}

\section{Citra Merek}

Pemasar perlu menyadari potensi desain untuk keuntungan merek atau bisnis merek. Desain yang digunakan secara bijak, dapat meningkatkan penjualan, membangun pasar baru, mengubah persepsi konsumen dan meningkatkan profitabilitas. Penelitian yang dilakukan oleh Farhan (2015) mengungkapkan bahwa desain produk sepatu merek Nike yang futuristic dan beragam diasosiasikan oleh konsumenya terhadap citra merek Nike yang positif. Penelitian Stompff (2010) mengemukakan bahwa perusahaan perlu memperhatikan kesesuaian desain produk dengan perspektif konsumen dalam menilai kegunaan fungsional produk karena berdampak pada penilaian terhadap merek.

Penelitian Rachman (2014) juga menemukan bahwa desain produk yang baik akan mempengaruhi perspektif konsumen terhadap merek produk tersebut. Penelitian lain oleh Anandya (2015) juga menemukan bahwa desain yang baik adalah desain yang memberikan produk keunikan yang membedakanya dengan merek yang lain, sehingga menciptakan citra merek yang baik dikarenakan keunikan dari desain produk tersebut.

Mengacu pada uraian diatas maka hipotesis yang dikembangkan adalah:

H7: Desain produk berpengaruh positif dan signifikan terhadap citra merek

\section{METODE PENELITIAN}

Penelitian ini dibentuk oleh variabel-variabel independen celebrity endorser, harga dan desain produk, variabel interverning citra merek, dan variabel dependen keputusan pembelia. Masing-masing variabel dibentuk oleh beberapa indikator berdasarkan definisi operasional berikut:

Tabel 1. Variabel Pengukuran dan Indikator Penelitian

\begin{tabular}{llll}
\hline Variabel & \multicolumn{1}{c}{ Definisi Variabel } & \multicolumn{1}{c}{ Sumber } & \multicolumn{1}{c}{ Indikator } \\
\hline Celeberity & Orang yang dapat & Salestio,et.al (2016) & Daya tarik \\
Endorser & menimbulkan & Rizki dan & Memiliki citra yang baik \\
& kepercayaan orang & Mudiantono (2016) & Keserasian dengan peran \\
& lain terhadap apa yang & & Mempunyai image yang \\
& dia sampaikan. & & dapat mewakili produk \\
& Shimp (2014) & & \\
\hline
\end{tabular}




\begin{tabular}{|c|c|c|c|}
\hline Harga & $\begin{array}{l}\text { Suatu nilai yang } \\
\text { diberikanterhadap } \\
\text { produk untuk } \\
\text { memposisikan } \\
\text { produknya lebih } \\
\text { unggul daripada } \\
\text { produk lain } \\
\text { Wicaksono (2016) }\end{array}$ & $\begin{array}{l}\text { Rizki dan } \\
\text { Mudiantono (2016) } \\
\text { Reven dan Ferdinand } \\
\text { (2017) }\end{array}$ & $\begin{array}{l}\text { Harga sesuai kualitas } \\
\text { pakaian } \\
\text { Harga terjangkau } \\
\text { Harga sesuai dengan } \\
\text { manfaat } \\
\text { Potonganharga(diskon } \\
\text { pembelian grosir) }\end{array}$ \\
\hline $\begin{array}{l}\text { Desain } \\
\text { Produk }\end{array}$ & $\begin{array}{l}\text { Suatu fitur produk } \\
\text { yang mempengaruhi } \\
\text { tampilan fisik dan } \\
\text { nilai gunanya yang } \\
\text { sesuai bagi } \\
\text { kebutuhan konsumen } \\
\text { Rachman (2014) }\end{array}$ & $\begin{array}{l}\text { Widyastuti dan Said } \\
\text { (2017) } \\
\text { Reven dan Ferdinand } \\
\text { (2017) }\end{array}$ & $\begin{array}{l}\text { Variasi Warna Pakaian } \\
\text { Variasi Model Pakaian } \\
\text { Beragam } \\
\text { Desain Pakaian UpTo Date } \\
\text { Desain nyaman digunakan }\end{array}$ \\
\hline Citra Merek & $\begin{array}{l}\text { Pemikiran atau } \\
\text { perasaan konsumen } \\
\text { mengenai suatu merek } \\
\text { Lee et.al, (2011) }\end{array}$ & $\begin{array}{l}\text { Rizki dan Mudianto } \\
\text { (2016) } \\
\text { Rahman dan Santoso } \\
\text { (2015) }\end{array}$ & $\begin{array}{l}\text { Mempunyai ciri khas } \\
\text { Reputasi merek baik } \\
\text { Merek dapat dipercaya } \\
\text { Mengeluarkan produk } \\
\text { bermutu }\end{array}$ \\
\hline $\begin{array}{l}\text { Keputusan } \\
\text { Pembelian }\end{array}$ & $\begin{array}{l}\text { Pengambilan } \\
\text { keputusan oleh } \\
\text { konsumen untuk } \\
\text { membeli suatu produk } \\
\text { yang diawali dengan } \\
\text { adanya kesadaran atas } \\
\text { pemenuhan kebutuhan } \\
\text { dan keinginan setiap } \\
\text { konsumen } \\
\text { Djatmiko dan Pradana } \\
(2016)\end{array}$ & $\begin{array}{l}\text { Rizki dan } \\
\text { Mudiantono (2017) } \\
\text { Rahman dan Santoso } \\
\text { (2015) } \\
\text { Reven dan Ferdinand } \\
\text { (2017) }\end{array}$ & $\begin{array}{l}\text { Membeli tanpa } \\
\text { pertimbangan } \\
\text { Berani mengambil resiko } \\
\text { pembelian } \\
\text { Kebanggan menggunakan } \\
\text { produk } \\
\text { Harga dari produk }\end{array}$ \\
\hline
\end{tabular}

Penelitian ini adalah penelitian Least Square) versi 3.27. kausalitas,dilakukan pada konsumen

Desstore Collection yang sudah melakukan pembelanjaan. Pengambilan sampel dilakukan dengan menggunakan metode probability sampling. Jumlah sampel dalam penelitian ini sebanyak 100 responden. Sumber data diperoleh dari penyebaran kuesioner online melalui media sosial Whatssap. Pengelolahan data menggunakan Software Smart PLS (Partial

\section{HASIL PENELITIAN DAN}

PEMBAHASAN

Analisis Jawaban Responden Terhadap Variabel Celebrity Endorser

Nilai indeks rata-rata celebrity endorser diperoleh 82,25. Sedangkan nilai tertinggi adalah mempunyai image yang dapat mewakili produk dengan indeks 86,20, disusul dengan indikator keserasian 
dengan peran 83,70 , kemudian indikator memiliki citra yang baik dan nilai terendah adalah daya tarik dengan nilai indekas 78,90. Hal ini menunjukkan bahwa keempat indikator tersebut telah dapat dijadikan tolak ukur dari variabel celebrity endorser.

Analisis Jawaban Respondedn Terhadap Variabel Harga

Nilai indeks rata-rata harga diperoleh 81,83. Sedangkan nilai tertinggi adalah mempunyai harga sesuai kualitas pakaian dengan indeks 83,40, disusul dengan indikator harga terjangkau dengan nilai indekas 82,30 dan yang terendah adalah harga terjangkau dan potongan harga dengan indekas 80,80. Hal ini menunjukkan bahwa keempat indikator tersebut telah dapat dijadikan tolak ukur dari variabel harga.

Analisis Jawaban Responden Terhadap Variabel Desain Produk

Nilai indeks rata-rata celedesain produk diperoleh 81,73. Sedangkan nilai tertinggi adalah variasi warna pakaian dan indikator desain up to date 82,80, kemudian indikator variasi model pakaian beragam 81,90 dan nilai terendah adalah desain nyaman digunakan dengan nilai indekas 80,00. Hal ini menunjukkan bahwa keempat indikator tersebut telah dapat Dalam penelitian ini analisa data hasil penelitian diolah dengan dijadikan tolak ukur dari variabel desain produk.

Analisis Jawaban Responden Terhadap Variabel Citra Merek

Nilai indeks rata-rata citra merek diperoleh 85,10 . Sedangkan nilai tertinggi adalah merek dapat dipercaya dengan indeks 87,300, disusul dengan indikator reputasi baik 86,10, kemudian indikator mengeluarkan produk bermutu 83,90 dan nilai terendah adalah mempunyai ciri khas dengan nilai indekas 83,10. Hal ini menunjukkan bahwa keempat indikator tersebut telah dapat dijadikan tolak ukur dari variabel citra merek.

Analisis Jawaban Responden Terhadap Variabel Keputusan Pembelian Nilai indeks rata-rata keputusan pembelian diperoleh 81,37 . Sedangkan nilai tertinggi adalah kebanggan menggunakan produk dengan indeks 82,40, disusul dengan indikator membeli tanpa pertimbangan 81,80, kemudian indikator berani mengambil resiko pembelian dan nilai terendah adalah harga dari produk dengan nilai indekss 80,20. Hal ini menunjukkan bahwa keempat indikator tersebut telah dapat dijadikan tolak ukur dari variabel keputusan pembelian.

\section{PENGUJIAN PLS}

bantuanSmartPLS 3.0. Berikut hasil pengolahan data dengan SmartPLS 


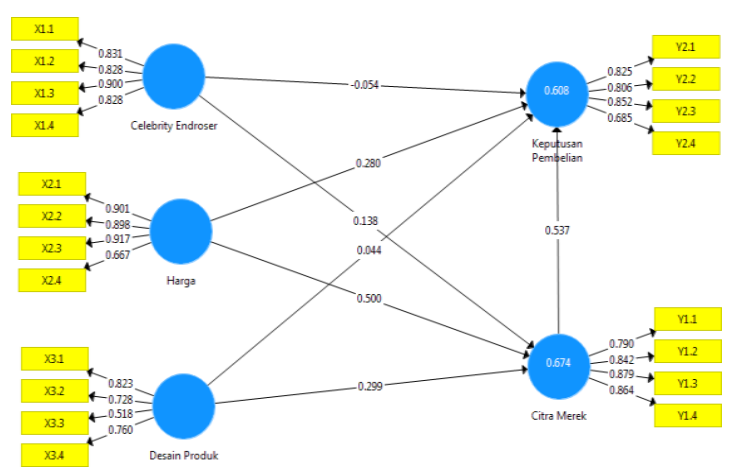

Gambar 2. Model Output Pengukuran

Tabel 2. Nilai Average Extracted (AVE)

\begin{tabular}{ll}
\hline \multicolumn{1}{c}{ Konstruk } & $\begin{array}{c}\text { Average Variance } \\
\text { Extracted (AVE) }\end{array}$ \\
\hline Celebrity endroser & 0,718 \\
Harga & 0,726 \\
Desain produk & 0,513 \\
Citra merek & 0,713 \\
Keputusan Pembelian & 0,631 \\
\hline \multicolumn{2}{c}{ Sumber: Pengolahan data dengan SmartPLS, 2018 }
\end{tabular}

Tabel 3. Discriminant Validity

\begin{tabular}{llllll}
\hline & $\begin{array}{c}\text { Celebrity } \\
\text { Endroser }\end{array}$ & $\begin{array}{c}\text { Citra } \\
\text { Merek }\end{array}$ & $\begin{array}{c}\text { Desain } \\
\text { Produk }\end{array}$ & Harga & $\begin{array}{c}\text { Keputusan } \\
\text { Pembelian }\end{array}$ \\
\hline Celebrity Endroser & 0,847 & & & & \\
Citra merek & 0,534 & 0,845 & & & \\
Desain Produk & 0,415 & 0,701 & 0,716 & & \\
Harga & 0,542 & 0,781 & 0,687 & 0,852 & 0,795 \\
Keputusan & 0,403 & 0,758 & 0,591 & 0,701 & \\
Pembelian & & & & \\
Sumber: Pengolahan data dengan SmartPLS, 2018 &
\end{tabular}

Tabel 4. Nilai R-Square

\begin{tabular}{lc}
\hline \multicolumn{1}{c}{ Konstruk } & \multicolumn{1}{c}{ Nilai R2 } \\
\hline Citra Merek & 0,674 \\
Keputusan Pembelian & 0,608 \\
\hline Sumber: Pengolahan data dengan SmartPLS, 2018
\end{tabular}


Tabel 5. Nilai Cronbach's Alpha dan Composite Realibility

\begin{tabular}{lll}
\hline & Cronbach's alpha & Composite Realibility \\
\hline Celebrity Endroser & 0,873 & 0,910 \\
Harga & 0,869 & 0,912 \\
Desain Produk & 0,670 & 0,804 \\
Citra Merek & 0,865 & 0,909 \\
Keputusan Pembelian & 0,805 & 0,901 \\
\hline
\end{tabular}

Sumber: Pengolahan data dengan SmartPLS, 2018

Tabel 6. Nilai Path Coefficient

\begin{tabular}{llllll}
\hline \multicolumn{1}{c}{ Korelasi } & \multicolumn{1}{c}{$\begin{array}{c}\text { Orginal } \\
\text { Sampel }(\mathbf{O})\end{array}$} & $\begin{array}{c}\text { Sampel } \\
\text { Mean }(\mathbf{M})\end{array}$ & $\begin{array}{c}\text { Standar } \\
\text { Deviation }\end{array}$ & T.statistic & P Values \\
\hline CE-CM & 0,138 & 0,136 & 0,073 & 1,892 & 0,059 \\
CE-KP & $-0,054$ & $-0,041$ & 0,086 & 0,624 & 0,533 \\
CM-KP & 0,537 & 0,529 & 0,112 & 4,787 & 0,000 \\
DP-CM & 0,299 & 0,307 & 0,096 & 3,131 & 0,002 \\
DP-KP & 0,044 & 0,056 & 0,107 & 0,412 & 0,681 \\
H-CM & 0,500 & 0,500 & 0,109 & 4,575 & 0,000 \\
H-KP & 0,280 & 0,274 & 0,132 & 2,117 & 0,035 \\
\hline
\end{tabular}

Sumber: Pengolahan data dengan SmartPLS, 2018

Tabel 7. Indirect Effects

\begin{tabular}{llllll}
\hline \multicolumn{1}{c}{ Korelasi } & \multicolumn{1}{c}{$\begin{array}{c}\text { Orginal } \\
\text { Sampel (O) }\end{array}$} & $\begin{array}{c}\text { Sampel } \\
\text { Mean (M) }\end{array}$ & $\begin{array}{c}\text { Standar } \\
\text { Deviation }\end{array}$ & T.statistic & P Values \\
\hline CE-CM-KP & 0,074 & 0,071 & 0,041 & 1,803 & 0,072 \\
DP-CM-KP & 0,161 & 1,63 & 0,064 & 2,515 & 0,012 \\
H-CM-KP & 0,269 & 0,264 & 0,081 & 3,321 & 0,001 \\
\hline
\end{tabular}

Sumber: Pengolahan data dengan SmartPLS, 2018

Analisa Outer ModelConvergent Validity

Berdasarkan Gambar 1 semua indikator memiliki faktor loading diatas 0,5, dan tabel 2 AVE diatas 0,5 dengan demikian semua indikator dinyatakan valid.

Discriminant validity

Dari tabel 2 diatas dapat dilihat bahwa nilai akar kuadrat dari AVE $(0,847$,
0,845, 0716, 0,852 dan 0,795) lebih besar dari masing-masing konstruk atau nilai akar AVE lebih besar dari 0,5.

Cronbach's alpha dan Composite reliability

Hasil pengujian reliabilitas dalam penelitian ini menunjukan bahwa secara umum variabel pengukuran yang digunakan dalam penelitian ini dapat 
dinyatakan reliabel, yakni menunjukan

Cronbach's alpha dan Composite reliability $>0,6$. Peneliti telah merangkum hasil pengujian reliabilitas pada Tabel 3 .

Analisa Inner Model

Tabel 4 menunjukkan nilai $\mathrm{R}$ square untuk variabel citra merek diperoleh sebesar 0,674, artinya untuk variabel citra merek diperoleh sebesar $67,4 \%$ menunjukan dipengaruhi variabel celebrity endroser, harga dan desain produk. Variabel keputusan pembelian diperoleh nilai $\mathrm{R}$-square 0,608 artinya variabel keputusan pembelian diperoleh sebesar $60,8 \%$ ini menunjukan dipengaruhi oleh variabel celebrity endroser, harga, desain produk dan citra merek.

\section{Pengujian Hipotesis}

\section{Hipotesis 1}

Hipotesis 1 pada penelitian ini adalah celebrity endorser berpengaruh positif dan signifikan terhadap keputusan pembelian. Hasil pengujian pengaruh variabel celebrity endorser terhadap keputusan pembelian adalah -0,054 sebagaimana diperlihatkan oleh koefisien jalurnya. Dilihat dari nilai T-statistic sebesar 0,624 lebih kecil dari ttabel 1,960 dan P-Values sebesar 0,533. P-Values 0,533 lebih besar dari nilaiprobabilitas 0,05 atau nilai $(0,000 \leq 0,05)$ artinya tidak signifikan. Hal ini berarti bahwa terdapat pengaruh negatif dari celebrity endorser terhadap keputusan pembelian. Dengan demikian hasil uji statistik ini menolak Hipotesis 1.

\section{Hipotesis 2}

Hipotesis 2 pada penelitian ini adalah harga berpengaruh positif dan signifikan terhadap keputusan pembelian. Hasil pengujian pengaruh variabel harga terhadap keputusan pembelian adalah 0,280 sebagaimana diperlihatkan oleh koefisien jalurnya. Dilihat dari nilai $\mathrm{T}$ statistic sebesar 2,117 lebih besar dari ttabel 1,960 dan P-Values sebesar 0,000. P-Values 0,035 lebih kecil dari nilai probabilitas 0,05 atau nilai $(0,000 \leq 0,05)$ artinya signifikan. Nilai signifikansi yang lebih kecil dari 0,05 menunjukkan bahwa terdapat pengaruh positif signifikan dari variabel harga terhadap keputusan pembelian. Dengan demikian hasil uji statistik ini menerima Hipotesis 2.

\section{Hipotesis 3}

Hipotesis 3 pada penelitian ini adalah desain produk berpengaruh positif dan signifikan terhadap keputusan pembelian. Hasil pengujian pengaruh variabel desain produk terhadap keputusan pembelian adalah 0,044 sebagaimana diperlihatkan oleh koefisien jalurnya. Dilihat dari nilai T-statistic sebesar 0,412 lebih kecil dari ttabel 1,960 dan P-Values sebesar 0,681. P-Values 0,681 lebih besar dari nilai probabilitas 0,05 atau nilai 
$(0,000 \leq 0,05)$ artinya tidak signifikan.

Dengan demikian variabel desain produk terhadap keputusan pembelian berpengaruh positif akan tetapi tidak signifikan. Dengan demikian hasil uji statistik ini menolak Hipotesis 3.

\section{Hipotesis 4}

Hipotesis 4 pada penelitian ini adalah citra merek berpengaruh positif dan signifikan terhadap keputusan pembelian. Hasil pengujian pengaruh variabel harga terhadap keputusan pembelian adalah 0,537 sebagaimana diperlihatkan oleh koefisien jalurnya. Dilihat dari nilai $\mathrm{T}$ statistic sebesar 4,784 lebih besar dari ttabel 1,960 dan P- Values sebesar 0,000. P-Values 0,001 lebih kecil dari nilai probabilitas 0,05 atau nilai $(0,000 \leq 0,05)$ artinya signifikan. Nilai signifikansi yang lebih kecil dari 0,05 menunjukkan bahwa terdapat pengaruh positif signifikan dari variabel citra merek terhadap keputusan pembelian. Dengan demikian hasil uji statistik ini menerima Hipotesis 4.

\section{Hipotesis 5}

Hipotesis 5 pada penelitian ini adalah celebrity endorser berpengaruh positif dan signifikan terhadap citra merek. Hasil pengujian pengaruh variabel celebrity endorser terhadap citra merek adalah 0,138 sebagaimana diperlihatkan oleh koefisien jalurnya. Dilihat dari nilai T-statistic sebesar 1,892 lebih kecil dari ttabel 1,896 dan P-Values sebesar 0,059. P-Values 0,059 lebih kecil dari nilai probabilitas 0,05 atau nilai $(0,000 \leq 0,10)$ artinya signifikan. Dengan demikian disimpulkan bahwa variabel celebrity endroser terhadap citra merek berpengaruh positif dan signifikan . Dengan demikian hasil uji statistik ini menerima Hipotesis 5.

\section{Hipotesis 6}

Hipotesis 6 pada penelitian ini adalah harga berpengaruh positif dan signifikan terhadap citra merek. Hasil pengujian pengaruh variabel harga terhadap citra merek adalah 0,500 sebagaimana diperlihatkan oleh koefisien jalurnya. Dilihat dari nilai $\mathrm{T}$ - statistic sebesar 4,575 lebih besar dari ttabel 1,960 dan P-Values sebesar 0,000. P-Values 0,000 sama dengan nilai probabilitas $(0,000 \leq 0,05)$ artinya signifikan. Nilai signifikansi yang sama dengan 0,000 menunjukkan bahwa terdapat pengaruh positif signifikan dari variabel harga terhadap citra merek. Dengan demikian hasil uji statistik ini menerima Hipotesis 6.

\section{Hipotesis 7}

Hipotesis 7 pada penelitian ini adalah desain produk, berpengaruh positif dan signifikan terhadap citra merek. Hasil pengujian pengaruh variabel desain produk terhadap citra merek adalah 0,299 sebagaimana diperlihatkan oleh koefisien jalurnya. Dilihat dari nilai T-statistic 
sebesar 3,131 lebih besar dari ttabel 1,960 dan P-Values sebesar 0,002. P-Values 0,000 sama dengan nilai probabilitas $(0,000 \leq 0,05)$ artinya signifikan. Nilai signifikansi yang lebih kecil dari 0,05 menunjukkan bahwa terdapat pengaruh positif signifikan dari variabel desain produk terhadap citra merek. Dengan demikian hasil uji statistik ini menerima Hipotesis 7.

\section{Pengujian Mediasi}

Dari Tabel 7 diatas bahwa hasil efek tidak langsung variabel celebrity endorser terhadap keputusan pembelian melalui citra merek P-Values $0,072>0,10$ ini signifikan pada taraf alfa 10\%. Efek tidak langsung desain produk terhadap keputusan pembelian melalui citra merek P-Values $0,012<0,05$ ini berarti signifikan. Sedangkan efek tidak langsung variabel harga terhadap keputusan pembelian $\mathrm{P}$-Values $0,001<0,05$ ini berarti signifikan.

Berdasarkan hasil diatas, maka citra merek dapat dikategorikan sebagai variabel intervening yang dapat memediasi untuk variabel celebrity endorser, harga, desain produk terhadap keputusan pembelian. Dengan demikian penempatan variabel citra merek sebagai variabel intervening dalam penelitian ini dapat dibuktikan/terbukti berpengaruh secara signifikan.

\section{KESIMPULAN}

\section{Pengaruh Celebrity Endroser Terhadap}

\section{Keputusan Pembelian}

Berdasarkan dari hasil pengujian bahwa terdapat pengaruh negatif dari celebrity endorser terhadap keputusan pembelian. Hasil penelitian ini sejalan dengan penelitian Munandar Chadafi (2016), McCormick, K (2016) dan Debasis P, et.al (2016), yang menyatakan bahwa celebrity endorser tidak berpengaruh terhadap keputusan pembelian. Hal ini menunjukkan bahwa konsumen tidak begitu mempertimbangkan celebrity endorser yang mempromosikan produkproduk yang dijual pada media sosial Shopee dalam penentuan keputusan mereka untuk membeli produk.

\section{Pengaruh Harga Terhadap Keputusan Pembelian}

Hasil penelitian ini membuktikan bahwa harga berpengaruh positif terhadap keputusan pembelian. Hasil penelitian ini sejalan dengan penelitian yang dilakukan oleh Evelina, DW dan Listyorini (2012), Rizki dan Mudiantono (2016) dan Reven dan Ferdinand (2017) memberikan hasil penelitian yang sama yaitu harga berpengaruh positif terhadap keputusan pembelian.Dari hasil analisis deskriftif yang menjelaskan bahwa menurut konsumen Desstore Collection, harga yang ditetapkan Desstore Collection terhadap 
produk pakaianya sudah sangat baik, hal ini berdampak pada mantapnya keputusan pembelian terhadap produk pakaian Desstore Collection.

\section{Pengaruh Desain Produk Terhadap}

Keputusan Pembelian

Berdasarkan hasil penelitian menunjukkan bahwa desain produk berpengaruh positif tetapi tidak signifikan terhadap keputusan pembelian. Hasil penelitian ini sejalan dengan penelitian yang dilakukan oleh Meiliani dan Ferdinand (2015) bahwa desain produk berpengaruh positif tetapi tidak signifikan terhadap keputusan pembelian. Dari hasil temuan ini menunjukkan bahwa konsumen tidak begitu mempertimbangkan desain produk Desstore Collection yang dijual pada media sosial Shopee dalam penentuan keputusan mereka untuk membeli produk.

\section{Pengaruh Citra Merek Terhadap}

\section{Keputusan Pembelian}

Hasil penelitian ini membuktikan bahwa pengaruh positif signifikan dari variabel citra merek terhadap keputusan pembelian. Hasil penelitian ini sejalan dengan penelitian yang dilakukan oleh Aghekyan Simonian, et.al (2012), Lee, et.al (2011) dan Oladepo dan Odunlami (2015) bahwa citra merek berpengaruh positif terhadap keputusan pembelian. Hal ini menjelaskan bahwa citra dari sebuah merek dapat membantu dalam menciptakan keputusan pembelian oleh konsumen. Dalam hal ini ditunjukkan bahwa reaksi konsumen akan dipengaruhi oleh familiaritas konsumen atas merek produk yang terkait dengan merek tersebut. Secara empiris diperoleh bahwa citra merek pakaian Desstore Collection sudah dinilai baik oleh konsumenya.

\section{Pengaruh Celebrity Endroser Terhadap}

\section{Citra Merek}

Hasil penelitian ini membuktikan bahwa celebrity endorser berpengaruh positif dan signifikan terhadap citra merek. Hasil penelitian ini sejalan dengan penelitian yang dilakukan oleh Rizki dan Mudiantono (2016), Wijaya dan Sugiharto (2015) yang menunjukkan hasil yang sama yaitu celebrity endorser berpengaruh positif terhadap citra merek. Hal ini terjadi dikarenakan responden menganggap penggunaan celebrity endorser pada produk Desstore Collection dapat membangun suatu citra merek yang positif.

\section{Pengaruh Harga Terhadap Citra Merek}

Hasil penelitian ini membuktikan bahwa harga berpengaruh positif dan signifikan terhadap citra merek. Hasil penelitian ini sejalan dengan penelitian yang dilakukan oleh Noerhodiah (2013) bahwa harga berpengaruh positif terhadap citra merek. Berdasarkan temuan harga 
yang ditetapkan oleh Desstore Collection memiliki pengaruh positif terhadap merek pakaian Desstore Collection, dimana harga yang sesuai kualitasnya dan manfaatnya, sehingga harga yang ditetapkan Desstore Collection meberikan citra merek yang baik untuk produk Desstore Collection tersebut

Pengaruh Desain Produk Terhadap Citra Merek

Hasil penelitian ini membuktikan bahwa desain produk berpengaruh positif dan signifikan terhadap citra merek. Hasil penelitian ini sejalan dengan penelitian yang dilakukan oleh Farhan (2015), Rahman (2015) dan Anandya (2015) bahwa desain produk berpengaruh positif terhadap citra merek. Berdasarkan temuan ini bahwa desain produk Desstore Collection sangat baik dan hal ini mempengaruhi perspektif konsumen terhadap merek Desstore Collection. Desain produk Desstore Collection memiliki ciri khas sendiri yang membedakanya dengan merek lain sehingga citra merek Desstore Collection baik dikarenakan desain produknya tersebut.

\section{SARAN DAN IMPLIKASI}

\section{Saran}

Meningkatkan kualitas produk dari kualitas bahan, jahitan dan desain.
Menciptakan desain-desain yang lebih unik, trendy dan memiliki ciri yang khas Mempertahankan harga yang sudah ditetapkan, mengingat faktor harga dalam penelitian ini adalah variabel dominan dalam pengambilan keputusan pembelian konsumen.

Model yang digunakan tidak harus selebriti yang dikenal, cukup oleh owner Desstore Collection itu sendiri atau model yang biasapun konsumen percaya bahwa produk Desstore Collection bagus dan berkualitas.

\section{Implikasi Teoritis}

Celebrity endorser tidak memiliki relasi dengan alasan pembelian konsumen. Sosok celebrity endorser tidak dapat menarik minat konsumen untuk melakukan pembelian pada produk di media sosial Shopee, Chadafi (2016). Konsumentidak begitu mempertimbangkan celebrity endorser yang mempromosikan produk yang dijual di Shopee dalam penentuan keputusan mereka untuk membeli produk.

Citra merek merupakan suatu cara bagi perusahaan membedakan produknya antara satu sama lain dan menciptakan ciri khas perusahaan tersendiri, dan citra merek yang baik serta memiliki ciri khas tersendri akan merangsang konsumen untuk membeli produk, Wu et. al (2011).

Citra merek adalah pemikiran atau 
perasaan konsumen mengenai suatu merek Lee, et.al (2011). Asosiasi konsumen terhadap merek yang baik tercipta dari desain produk yang baik dan harga yang tepat. Citra merek yang positif akan terbentuk dari desain produk yang dapat memberikan manfaat bagi konsumen.

Penelitian mendukung konsep penetapan harga yang kompetitif yang dikemukakan oleh Wicaksono (2016), yaitu dimana harga kompetitif adalah suatu nilai yang diberikan terhadap produk untuk memposisikan produknya lebih unggul daripada produk lain dengan memperhatikan daya beli konsumen dan daya saing para pesaingnya, penentapan harga yang kompetitif dengan memperhatikan daya beli konsumen dan daya saing perusahaan pesaing akan semakin menentukan maksud konsumen untuk membeli produk.

\section{Implikasi Manajerial}

Penggunaan celebrity endorser tidak serta merta akan meningkatkan keputusan pembelian, karena pada beberapa konsumen tidak begitu mempertimbangkan celebrity endorser yang mempromosikan produk yang dijual pada media sosial Shopee.

Celebrity endorser merupakan salah satu faktor pendukung sisi psikologis yang mampu mempengaruhi sikap dan keyakinan konsumen akan produk.
Celebrity endorser akan bersikap atau bertindak sebagai penyalur, pembicara, dan penghubung sebuah iklan untuk memperkenalkan sebuah produk kepada konsumen sehingga penggunaan celebrity endorser dianggap sebagai perwakilan (represntasi) dari identitas produk.

Harga kompetitif merupakan faktor terpenting dalam mempengaruhi keputusan pembelian. Sebelum melakukan keputusan pembelian, kebanyakan konsumen akan melihat harga produk terlebih dahulu. Jika harganya terjangkau dengan daya beli konsumen dan dipresepsikan bersaing dengan harga produk merek lain, maka konsumen akan semakin mantap memutuskan membeli produk merek tersebut.

Desain produk menjadi salah satu faktor penting dalam pertimbangan konsumen untuk memutuskan membeli produk. Desain produk yang baik akan diasosiasikan konsumen terhadap citra merek yang baik, yang pada akhirnya meyakinkan konsumen untuk membeli produk tersebut. Desstore Collection dapat meningkatkan desain produk pakaianya dengan menciptakan beragam modelmodel terbaru yang memiliki nilai estetik yang tinggi, dan tentunya sesuai dengan perkembangan fashion terbaru.

Citra merek merupakan faktor yang paling mempengaruhi konsumen dalam 
melakukan keputusan pembelian. Citra merek yang baik dipersepsikan oleh konsumen dari nilai positif yang ada pada atribut produk, sehingga akan menentukan maksud konsumen untuk membeli produk dengan pasti. Desstore Collection dapat menjadi semakin baik dengan terus menjaga kestabilan kualitas pakaian, dan mengembangkan produk pakaian yang baru dan variatif secara berkelanjutan.

\section{Keterbatasan Penelitian}

Penelitian ini tidak dapat membuktikan adanya pengaruh signifikan antara celebrity endorser terhadap keputusan pembelian. Dalam penelitian selanjutnya diharapkan mampu membuktikan adanya pengaruh variabel celebrity endorser terhadap keputusan pembelian.

Penelitian ini tidak dapat membuktikan adanya pengaruh signifikan antara desain produk terhadap keputusan pembelian

Dalam penelitian ini variabel yang digunakan untuk mengetahui keputusan pembelian di Shopee terbatas hanya pada tiga variabel dependen dan satu variabel intervening, untuk hasil penelitian yang lebih baik alangkah baiknya menambahkan variabel lain untuk mengetahui pengaruh terhadap keputusan pembelian di Shopee yang lebih beragam.
Dalam penelitian ini pengambilan data hanya dilakukan menggunakan kuesioner sehingga kedalaman informasi masih kurang dalam menggali keputusan pembelian yang dipengaruh oleh celebrity endorser, harga dan desain produk dengan dimediasi oleh citra merek.

\section{DAFTAR PUSTAKA}

Anandya, Rizky .2015. Analisis Pengaruh Desain Produk, Persepsi Harga dan Kualitas Produk Terhadap Citra Merek Untuk meningkatkan MInat Beli Konsumen Sepatu Adidas Original (Studi Kasus Pada Masyarakat di Kota Semarang). Skripsi. Universitas Diponegoro.

Chan et.al.,2013. Impact Of Celebrity Endorsement In Advertising On Brand Image Among Chinese Adolescents, Young Consumers, Journal Of. Journal Of Consumer Marketing. Vol. 14 Issue: 2, pp.167-179, Hong Kong Baptist University, Hong Kong, China.

Evelina,Lina, Handoyo DW dan Sari Listyorini. 2012. Pengaruh Citra Merek,Kualitas Produk, Harga dan Promosi Terhadap Keputusan Pembelian Kartu Pedana TelkomFlexi (studi Kaus Pada Konsumen TelkomFleksi di Kecamatan Kota Kudus Kabupaten Kudus). Dipenogoro of Journal Social and Politics.

Farhan,Muhammad Yusuf. 2015. Analisis

Pengaruh Citra Merek, Desain Produk dan Kualitas Produk Terhadap Keputusan Pembelian (Studi Kasus Pada Konsumen Produk Nike Indonesia. Journal Management. Universitas

Diponegoro, Semarang.

Indraswari Ni Md mahadewi dan Komang, 
A. Pramudana. 2014. Pengaruh Kredibilitas Celebrity Endroser dan Kewajaran Harga Terhadap Niat Beli Konsumen. Jurnal Manajemen. Fakultas Ekonomi dan Bisnis Universitas Udayana

Knight, Elina Halonen and Leila Hurmerinta. 2010. Who Endorses Whom? Meaning Transfer in Celebrity Endorsement. Journal of Product and Brand Management. 19(6), pp:452-460.

Lee,Hsiang Ming et.al.,2011. Brand Image Strategy Affects Brand Equity After M\&A.European Journal of Marketing. National Taiwan University. Taipei Taiwan.McCormick, K. 2016. Celebrity Endorsements: Influence Of a Product-Endroser Macth On Millenials Attitudes And Purchase Intention

Rachman,Januar Bayu dan Suryono Budi Santoso.2015. Analisis Pengaruh Desain Produk dan Promosi Terhadap Kemantapan Keputusan Pembelian yang di Mediasi oleh Citra Merek. Jurnal Management. Universitas Dipenogoro. Semarang

Reven Daniel dan Augusty Tae Ferdinand.2017. Analisis Pengaruh Desain Produk,Kualitas Produk, Harga Kompetitif, Dan Citra Merek Terhadap Keputusan Pembelian (Studi Pada Pelanggan Nesty Collection Jakarta). Jurnal Management. Universitas Diponegoro, Semarang

Rizki, Sinta Pamudyaning dan Mudiantono. 2016. Analisis Pengaruh Brand Ambassador, Kualitas Produk dan Harga Terhadap Brand Image Serta Dampaknya Rerhadap Keputusan. Jurnal Manajemen. Semarang

Robby,S., Augusty T.,F., dan I Made, S. 2016. Peningkatan Keputusan Pembelian Strategi Promosi Penjualan, Brand Positioning dan
Perceived Quality yang Dipengaruhi Oleh Celebrity Endorse dan Inovasi Produk. Jurnal Sains Pemasaran Indonesia. Semarang

Sabunwala Zohra, 2013. Impact of Celebrity Brand Endorsement on Brand Image and Product Purchases-A Study for Pune Region of India. International Journal of Research in Business Management. 1(6): h: 37-42

Widyastuti, Sri Dan Muhammad Said. 2017.Consumer Consideration in Purchase Decision of SPECS Sports Shoes Product through Brand Image, Product Design and Price Perception. International Journal of Supply Chain Management. Pancasila University. Jakarta

Wu,Paul C.S., Gary Yeong-Yuh Yeh, dan Chieh-Ru Hsiao, 2010. The Effect of Store Image and Service Quality on Brand Image and Purchase Decision for Private Label Brand. Australasian Marketing Journal. Elsevier

Yulihasri, Md. Aminul, I., Ku, A., Ku, D. 2011. Factors that Influence Customers' Buying Intention on Shopping Online. International Journal of Marketing Studies, 3(1), 128. 
PROGRESS

Jurnal Pendid ikan, Akuntansi dan Keuangan Universitas Banten Jaya
Vol 3 No. 1, Februari 2020

E-ISSN 2622-7037 |P-ISSN 2623-0763 